Archives of Agriculture and Environmental Science

\title{
Performance of tropical sugar beet (Beta vulgaris L.) as influenced by date of harvesting
}

\author{
Swapan Kumar Paul ${ }^{1^{*}}$ (D) , Rifat Alam Joni ${ }^{1}$, Md. Abdur Rahman Sarkar ${ }^{1}$, Md. Sohrab Hossain ${ }^{2}$ and \\ Shabuj Chandra Paul ${ }^{1}$ \\ ${ }^{1}$ Department of Agronomy, Bangladesh Agricultural University, Mymensingh 2202, BANGLADESH \\ ${ }^{2}$ Bangladesh Sugarcrop Research Institute, Ishurdi, Pabna, BANGLADESH \\ *Corresponding author's E-mail: skpaul@bau.edu.bd
}

\section{ARTICLE HISTORY}

Received: 20 February 2019

Revised received: 24 February 2019

Accepted: 02 March 2019

\section{Keywords}

Date of harvesting

Juice quality

Tropical sugar beet

Yield

\section{ABSTRACT}

An experiment was conducted at the Agronomy Field Laboratory, Bangladesh Agricultural University, Mymensingh during November 2017 to April 2018 to study the effect of date of harvesting on the yield and quality of tropical sugar beet. The experiment comprised seven varieties viz. SV 889, SV 892, SV 893, SV 894, SZ 35, KWS Serenada and KWS Danicia and two dates of harvesting viz. 135 days after sowing (DAS) and 155 DAS. The experiment was laid out in a randomized complete block design with three replications. Variety, date of harvesting and their interaction showed significant effect on crop characters, beet yield and juice quality of tropical sugar beet. The highest beet length $(23.50 \mathrm{~cm})$, individual beet weight $(591.6 \mathrm{~g})$ and beet yield ( $59.16 \mathrm{t} \mathrm{ha}^{-1}$ ) were recorded in SV 894 while the highest brix (15.42\%) was observed in SV 893. The lowest beet yield (40.25 $\mathrm{t} \mathrm{ha}^{-1}$ ) and brix (13.92\%) were observed in KWS Danicia. In case of date of harvesting, the highest beet length $(24.26 \mathrm{~cm})$, beet girth $(25.40 \mathrm{~cm})$, individual beet weight $(536.07 \mathrm{~g})$ and beet yield $\left(53.60 \mathrm{t} \mathrm{ha}^{-1}\right)$ were observed at 155 DAS harvest while the highest brix (14.66\%) was recorded at 135 DAS harvest. In interaction, the highest beet length $(25.67 \mathrm{~cm})$, individual beet weight $(681.2 \mathrm{~g})$ and beet yield $\left(68.12 \mathrm{t} \mathrm{ha}^{-1}\right)$ were recorded in SV 894 with 155 DAS harvest whereas the lowest beet yield (32.03 $\mathrm{t} \mathrm{ha}^{-1}$ ) was recorded in the interaction in KWS Danicia with 135 DAS harvest. From this study, it may be concluded that SV 894 appears as the promising variety that can be harvested at 155 DAS.

(C)2019 Agriculture and Environmental Science Academy

Citation of this article: Paul, S.K., Joni, R.A., Sarkar, M.A.R., Hossain, M.S. and Paul, S.C. (2019). Performance of tropical sugar beet (Beta vulgaris L.) as influenced by date of harvesting. Archives of Agriculture and Environmental Science, 4(1): 19-26, https://dx.doi.org/10.26832/24566632.2019.040103

\section{INTRODUCTION}

Sugar beet (Beta vulgaris L.), the second source of sugar all over the world belongs to the member of the Chenopodiaceae family. It is a temperate crop whose root contains high concentration of sucrose and is successfully grown on a commercial scale for sugar production. The international company Syngenta developed and successfully introduced a new sugar beet that can be grown under tropical climatic condition, which is known as tropical sugar beet. Sugar beet contributes about $30 \%$ of the world's sugar for human consumption (Bairagi et al., 2013). This crop is also a promising alternative energy crop for the production of ethanol. In Bangladesh, about 25\% sugar demand meeting domestically from sugarcane and rest $75 \%$ sugar demand is fulfilled by importation (Rahman et al., 2016). Sugar beet matures within 5 to 6 months and its root contains 16-19\% sucrose with a recovery of $12-14 \%$.

Sugarcane is a long duration crop thus farmers are discouraged to continue its production and moving towards short duration crop like maize and vegetables for higher profit. In this regard, sugar beet might be an excellent alternative of sugarcane if processing facilities are developed in the sugar mills. In Bangladesh, most of the sugar mills remain idle for a particular period due to acute shortage of sugarcane. On the other hand, sugar 
beet crop matures in March-April when the crushing season of sugarcane is nearly over in our country. In this situation sugar beet is coming up as the best alternative of sugarcane for production of sugar and ethanol. Feasibility of sugar beet cultivation in Bangladesh is under trial although some people are growing low sucrose containing genotype as salad and vegetable purposes. Thus, it is necessary for selection of suitable genotype to promote sugar beet as supplementary sugar based cropping system in Bangladesh. The performance of tropical sugar beet varieties was reported by Rahman et al. (2006) and Hossain et al. (2011). Suitable variety with proper fertilization influences the growth, yield and sugar recovery of tropical sugar beet (Seadh et al., 2013 and Bairagi et al., 2013).

Harvesting age is one of the main factors which directly affects the maturity consequently juice quality. Delay in harvest enhanced root yield and extractable sugar content was reported by Lauer (1995). Delay harvest increased in sugar content in roots in comparison with the earliest harvest (Shalaby et al., 2011). Abo-El Magd et al. (2003) noticed that delay harvest significant increase the root length, diameter, root fresh weight plant $^{-1}$, sucrose $\%$, as well as root and sugar yields fed ${ }^{-1}$. Azzazy et al. (2007) and El-Sheikh et al. (2009) harvested sugar beet varieties at 210 days from sowing and found significant improvement on root weight, sucrose $\%$, impurities, i.e. $\mathrm{Na} \%$ and $\mathrm{K} \%$, as well as root and sugar yields $\mathrm{fed}^{-1}$, than the other two harvest dates 180 and 195 days from sowing in both seasons. Postponement of the time of harvest increased average root yield of sugar beet was reported by Heidari et al. (2008). From the above discussion it seems that suitable genotype and time of harvesting is very important for maximizing yield and quality of sugar beet. Therefore, the present study was undertaken with a view to evaluating some tropical sugar beet genotypes with various harvesting time under Bangladesh condition.

\section{MATERIALS AND METHODS}

\section{Experimental site and experimentation}

The experiment was carried out at the Agronomy Field Laboratory, Bangladesh Agricultural University, Mymensingh during November 2017 to April 2018. The experimental field was located at $24^{\circ} 75^{\prime} \mathrm{N}$ latitude and $90^{\circ} 50^{\prime} \mathrm{E}$ longitude at an average altitude of $18 \mathrm{~m}$. It belongs to non-calcareous dark grey floodplain soil under the Sonatala series of the Old Brahmaputra Floodplain under Agro-Ecological Zone (AEZ-9) (UNDP and FAO, 1988). The soil was silty loam in texture having $\mathrm{pH} 6.8$ and low in organic matter content (1.67\%).

The experiment comprised seven varieties viz. SV 889, SV 892, SV 893, SV 894, SZ 35, KWS Serenda and KWS Danicia and two harvesting dates viz. 135 DAS and 155 DAS with three replications. The experiment was conducted in a randomized complete block design with 3 replications. The size of the unit plot was 5.0 $\mathrm{m}^{2}(2.5 \mathrm{~m} \times 2.0 \mathrm{~m})$. Each block was separated by $1.0 \mathrm{~m}$. The distances between two adjacent plots were $0.5 \mathrm{~m}$. The experimental land was ploughed well by tractor on 9 November, 2017. The deep ploughing and cross ploughing were done four times followed by leveling with a ladder. The corners of the experimental field were trimmed by spade and large colds were broken into small pieces by wooden hammer. Weeds, stubble and crop residues were removed from the field and the land were ready for a laying out the experiment on 20 November 2017. The land was uniformly fertilized with N-P-K-S-Zn-B at the rate of 13525-133-18-3.5-1.2 $\mathrm{kg} \mathrm{ha}^{-1}$ through Urea, Tripple super phosphate (TSP), Muriate of Potash (MoP), Gypsum, Zinc Sulphate, and Boric acid. The whole amount of TSP, MoP, Gypsum, Zinc Sulphate and Boric acid were applied at final land preparation. Urea as top dressed in three equal splits at 20,40 and 60 day after sowing (DAS). Seed of seven genotypes were sown on 24 November 2017 after soaking in water where the distance between two lines was $50 \mathrm{~cm}$ and seed to seed $20 \mathrm{~cm}$. Two seeds were placed in a hill. Four hand weeding were done very carefully at 15, 30, 45 and 60 DAS. Thinning and gap filling were done after three weeks of sowing to maintain proper plant population. Irrigations were done four times at 40, 60, 90 and 120 DAS. Drains made during earthing up were used for irrigation and drainage purpose. Some plots were infected by sclerotium root rot disease. The fungicide named Ridomil gold was sprayed @ $5 \mathrm{ml} \mathrm{L}^{-1}$ of water by hand sprayer. The harvesting was done two times according to treatment. The first harvesting of each was completed on 08 April 2018 (135 DAS) and the second harvesting was done on 27 April 2018 (155 DAS).

\section{Measurement of leaf chlorophyll content}

Determination of Soil-Plant-Analysis Development (SPAD) Value. Leaf chlorophyll content may be used as an indirect indicator of crop $\mathrm{N}$ status. With the help of SPAD meter (Model SPAD-502, Minolta crop, Ramsey, NJ), chlorophyll content of tropical sugarbeet was measured during harvest. The instrument measures transmission of red light at $650 \mathrm{~nm}$, at which chlorophyll absorbs light, and transmission of infrared light at $940 \mathrm{~nm}$, at which no absorption occurs. The chlorophyll meter readings have been positively correlated with destructive chlorophyll measurements in many crop species (Zhu et al., 2012). The instrument calculates a SPAD value on the basis of these two transmission values that is well correlated with chlorophyll content.

\section{Yield components and yield}

After harvesting, plants were washed and cleaned by removing dead and dried leaves and soil adhering to beets. Data on plant characters and yield components were recorded from ten randomly selected plants from each plot at every harvest. Beet yield was recorded from the whole plot harvest and converted to $\mathrm{tha}^{-1}$.

\section{Brix (\%) measurement in beet juice}

Refractometer (ATAGO) is used to measure this parameter. It was used twice at 135 DAS and 155 DAS (at harvest) respectively. Five beets of each plot were collected. The outside skin of sugar beet root was removed with the help of a sharp knife and sliced into small pieces as well as to extract a drop of 
juice by using mortar and pestle. Then the juice was transferred into the prism of the Refractometer and also closed the day light plate to get the accurate measurement of brix (\%) observed by eyepiece and averaged the value to get mean data per plot.

\section{Statistical analysis}

All the collected data were analyzed using analysis of variance (ANOVA) technique and the significance of mean differences were measured by Duncan's Multiple Range Test (DMRT) as described by Gomez and Gomez (1984).

\section{RESULTS AND DISCUSSION}

\section{Plant height}

A significant variation in plant height was observed due to variety. Plant height measured due variety ranged from 35.83 $\mathrm{cm}$ to $42.00 \mathrm{~cm}$ (Table 1). The tallest plant $(42.00 \mathrm{~cm}$ ) was recorded in SV 893 which was statistically identical with SV 892 $(41.33 \mathrm{~cm})$ and shortest one $(35.83 \mathrm{~cm})$ was found in KWS Danicia. It might be occurred due to the variability of genetic inherent characters in the varieties. This result also corroborated with Paul et al. (2018a) who reported that plant height differs with variety. Plant height significantly influenced by date of harvesting. The taller plant $(40.71 \mathrm{~cm})$ was recorded at 135 DAS harvest and the shorter one $(37.21 \mathrm{~cm})$ was found at 155 DAS harvest. Delay harvest showed shorter plant due to broader leaf died in course of time. The interaction between varieties and date of harvesting had significant influence on plant height. The tallest plant $(45.17 \mathrm{~cm})$ was obtained in SV 892 with 135 DAS harvest which was statistically identical with SV $893(42.67 \mathrm{~cm})$ at 155 DAS harvest and the shortest plant $(33.50 \mathrm{~cm})$ was recorded in KWS Danicia with harvest at 155 DAS (Table 3). Similar result was reported by Oldemeyer et al. (1997) who reported that plant height increased up to 120 DAS.

\section{Number of leaves plant ${ }^{-1}$}

The number of leaves plant ${ }^{-1}$ was ranged from 11.16 to 12.86 (Table 1). The highest number of leaves plant ${ }^{-1}$ (12.86) was obtained in SV 892 which was statistically identical with SV 889 and SV 893 while the lowest number of leaves plant ${ }^{-1}$ (11.16) was recorded in SZ 35. The number of leaves plant ${ }^{-1}$ varies with different genotypes due to different environmental condition that was reported by Islam et al. (2012). Leaf number differed significantly at different date of harvesting. The influence of date harvesting on leaf number was maximum (13.53) at 135 DAS harvest where the minimum leaf number plant ${ }^{-1}$ (10.76) was found at 155 DAS harvest. The vegetative period of sugar beet was longer and this vegetative period increased leaf number plant ${ }^{-1}$ in course of time and declined at harvest. Similar result was reported by Paul et al. (2018a). Leaf number had significant variation due to interaction between variety and harvesting time. The maximum leaf number plant $^{-1}$ (14.67) was observed in KWS Danicia with date of harvesting at 135 DAS which was at par with SV 889 (14.28) at 135 DAS harvest and the minimum leaf number plant ${ }^{-1}$ (9.67) was found in SV 894 with the date of harvesting at 155 DAS.

\section{Leaf chlorophyll content}

The chlorophyll content of leaves (SPAD value) of TSB in different varieties showed substantial differences at harvesting time. The SPAD value during harvesting time ranged from 32.30 to 40.92 (Table 1). The highest SPAD value (40.92) was obtained in SV 893 that was statistically identical with SV 889 (40.22) while the lowest one (32.30) was recorded in KWS Serenada. Chlorophyll contents in leaves (SPAD value) were influenced significantly due to date of harvesting. Chlorophyll contents were significantly higher (42.79) at 135 DAS harvest while lower value (33.74) was recorded at 155 DAS harvest (Table 2). Similar trend was reported by Paul et al. (2018a) and Paul et al. (2018b) who noticed that chlorophyll contents started to reduce due to maturity at harvest. The interaction between varieties and date of harvesting influenced significantly on SPAD value. The contribution of variety and date of harvesting for variation in SPAD value indicated that leaf area was the most influential factor for determining SPAD than the other parameters. The highest value (48.13) was observed in SV 893 with the harvesting date at 135 DAS which was similar to SV 889 (46.65) at the same harvesting date whereas the lowest one (28.77) was found in KWS Serenada with 155 DAS harvest. Usually chlorophyll content in leaves of sugar beet increased sharply in course of time up to 80 DAS and thereafter declined until harvesting. Chlorophyll content was maximum at 135 DAS harvest rather than at 155 DAS.

\section{Shoot length}

Shoot length was significantly influenced by variety. Shoot length due to variety ranged from $30.83 \mathrm{~cm}$ to $38.00 \mathrm{~cm}$ (Table 1). The longest shoot length $(38.00 \mathrm{~cm})$ was obtained in SV 892 followed by the variety KWS Serenada $(34.83 \mathrm{~cm})$ and the shortest one $(30.83 \mathrm{~cm})$ was recorded in KWS Danicia. It might be caused due to the variability of genetic makeup in the varieties. The length of leaves was statistically significant due to the influence of date of harvesting. The highest shoot length was recorded maximum $(34.47 \mathrm{~cm})$ at 135 DAS harvest where the minimum shoot length $(32.38 \mathrm{~cm})$ was obtained at 155 DAS harvest. Reduction of shoot length occurred from early to second harvest that was reported by Shewate et al. (2009). Shoot length significantly varied due to interaction between varieties and date of harvesting. The longest shoot $(40.83 \mathrm{~cm})$ was obtained in SV 892 associated with the date of harvesting at 135 DAS followed by KWS Serenda with harvesting date at 135 DAS and the shortest shoot $(29.17 \mathrm{~cm})$ was achieved with KWS Danicia with 155 DAS harvest (Table 3).

\section{Top weight plant $^{-1}$}

The variation due to varieties was significant for plant top weight (Table 1). Result showed that the top weight observed due to variety ranged from $82.92 \mathrm{~g}$ to $121.0 \mathrm{~g} \mathrm{plant}^{-1}$. The maximum top weight plant ${ }^{-1}(121.0 \mathrm{~g})$ was recorded in SV 889 followed by SV 892 (102.9 g) and the lowest one (82.92 g) was observed in SZ 35. Top weight showed a significant response to date of harvesting. The result indicated that the maximum value 
(115.9 g) for top weight plant ${ }^{-1}$ was observed at 135 DAS harvest whereas the minimum value $(84.07 \mathrm{~g})$ was recorded at 155 DAS harvest (Table 2). Similar result was reported by Heidari et al. (2008), who showed that top weight of sugar beet became lower due to leaf maturity at delay harvesting. Top weight plant ${ }^{-1}$ showed a significant response due to interaction effect of varieties and date of harvesting. The maximum top weight plant ${ }^{-1}$ (152.0 g) was recorded in SV 889 with 135 DAS harvest followed by SV 892 (125.0 g) with 135 DAS harvest whereas the minimum top weight plant ${ }^{-1}(70.50 \mathrm{~g})$ was found in SZ 35 with 155 DAS harvest (Table 3).

Top yield

Top yield showed a significant response to varieties. Top yield affected due to variety ranged from 8.29 to $12.10 \mathrm{t} \mathrm{ha}^{-1}$ (Table 1). The highest top yield (12.10 $\left.\mathrm{t} \mathrm{ha}^{-1}\right)$ was obtained in SV 889 followed by SV $892\left(10.29 \mathrm{t} \mathrm{ha}^{-1}\right)$ and the lowest top yield $(8.29 \mathrm{t}$ $\mathrm{ha}^{-1}$ ) was recorded in SZ 35. Top yield of sugar beet was significantly influenced by date of harvesting. The top yield of sugar beet was higher ( $\left.11.59 \mathrm{t} \mathrm{ha}^{-1}\right)$ at 135 DAS harvest and the lower top yield $\left(8.40 \mathrm{t} \mathrm{ha}^{-1}\right)$ was recorded at 155 DAS harvest. Top yield was influenced by weather condition and duration of sugar beet harvesting (Heidari et al., 2008). Top yield showed a significant response due to interaction effect of variety and date of harvesting. The maximum top yield $\left(15.20 \mathrm{t} \mathrm{ha}^{-1}\right)$ was recorded in SV 889 with 135 DAS harvest followed by SV $892(12.50 \mathrm{t}$ $\mathrm{ha}^{-1}$ ) with 135 DAS harvest whereas the minimum top yield $\left(7.05 \mathrm{t} \mathrm{ha}^{-1}\right)$ was found in SZ 35 with 155 DAS harvest.

Table 1. Effect of variety on the crop characters, yield components, yield and quality of tropical sugar beet.

\begin{tabular}{|c|c|c|c|c|c|c|c|c|c|c|c|}
\hline Variety & $\begin{array}{l}\text { Plant } \\
\text { height } \\
\text { (cm) }\end{array}$ & $\begin{array}{l}\text { No. of } \\
\text { leaves } \\
\text { plant }^{-1}\end{array}$ & $\begin{array}{l}\text { Chlorophyll } \\
\text { content } \\
\text { (SPAD } \\
\text { value) }\end{array}$ & $\begin{array}{l}\text { Shoot } \\
\text { length } \\
(\mathrm{cm})\end{array}$ & $\begin{array}{l}\text { Top } \\
\text { weight } \\
\text { plant }^{-1} \\
\text { (g) }\end{array}$ & $\begin{array}{l}\text { Top } \\
\text { yield } \\
\left(\mathrm{t} \mathrm{ha}^{-1}\right)\end{array}$ & $\begin{array}{l}\text { Beet } \\
\text { length } \\
(\mathrm{cm})\end{array}$ & $\begin{array}{l}\text { Beet } \\
\text { girth } \\
(\mathrm{cm})\end{array}$ & $\begin{array}{l}\text { Individual } \\
\text { beet } \\
\text { weight (g) }\end{array}$ & $\begin{array}{l}\text { Beet } \\
\text { yield } \\
\left(\mathrm{t} \mathrm{ha}^{-1}\right)\end{array}$ & $\begin{array}{l}\text { Brix } \\
(\%)\end{array}$ \\
\hline SV 889 & $39.30 \mathrm{~b}$ & 12.14ab & $40.22 a$ & $33.27 \mathrm{bc}$ & 121.0a & $12.10 a$ & $22.75 a b$ & $23.00 b c$ & $506.1 \mathrm{~b}$ & $50.61 \mathrm{~b}$ & $15.00 \mathrm{a}$ \\
\hline SV 892 & $41.33 a$ & $12.86 a$ & $40.19 a$ & $38.00 a$ & $102.9 \mathrm{~b}$ & $10.29 \mathrm{~b}$ & $22.58 a b$ & $26.50 a$ & $494.5 \mathrm{~b}$ & $49.45 b$ & $14.17 \mathrm{~b}$ \\
\hline SV 893 & $42.00 a$ & 12.14ab & $40.92 a$ & $32.50 \mathrm{~cd}$ & $99.92 b$ & $9.993 b$ & $20.83 c$ & $22.83 b c$ & $423.3 c$ & $42.33 c$ & $15.42 \mathrm{a}$ \\
\hline SV 894 & $38.97 \mathrm{~b}$ & $11.78 \mathrm{bc}$ & $39.81 a$ & $31.58 \mathrm{~cd}$ & $99.25 b$ & $9.926 \mathrm{~b}$ & $23.50 a$ & $23.92 b$ & $591.6 a$ & $59.16 a$ & $14.33 b$ \\
\hline SZ 35 & $38.42 b c$ & $11.16 \mathrm{c}$ & $36.55 b$ & $33.00 \mathrm{bc}$ & $82.92 c$ & $8.292 c$ & $21.42 c$ & $21.67 c$ & $429.2 c$ & $42.92 c$ & $14.33 b$ \\
\hline $\begin{array}{l}\text { KWS } \\
\text { Serenada }\end{array}$ & $36.89 \mathrm{~cd}$ & 12.11ab & $32.30 c$ & $34.83 b$ & $97.17 b$ & $9.717 b$ & $22.42 b$ & $24.00 b$ & $467.9 b$ & $46.79 \mathrm{~b}$ & $14.17 \mathrm{~b}$ \\
\hline $\begin{array}{l}\text { KWS } \\
\text { Danicia }\end{array}$ & $35.83 d$ & $12.84 a$ & $37.90 \mathrm{~b}$ & $30.83 d$ & $96.75 b$ & $9.675 b$ & $22.42 b$ & $24.25 b$ & $402.5 c$ & $40.25 c$ & $13.92 b$ \\
\hline Sx & 0.646 & 0.271 & 0.608 & 0.629 & 3.59 & 0.219 & 0.307 & 0.444 & 13.17 & 1.31 & 0.211 \\
\hline $\begin{array}{l}\text { Level of } \\
\text { significant }\end{array}$ & $* *$ & $* *$ & $* *$ & $* *$ & $* *$ & $* *$ & $* *$ & $* *$ & $* *$ & $* *$ & $* *$ \\
\hline CV (\%) & 4.06 & 5.46 & 3.89 & 4.60 & 8.80 & 5.37 & 3.38 & 4.58 & 6.81 & 6.81 & 3.57 \\
\hline
\end{tabular}

In a column, mean values with same letter (s) or without letter do not differ significantly whereas mean values with dissimilar letter differ significantly (as per DMRT); ${ }^{* *}=$ Significant at $1 \%$ level of probability.

Table 2. Effect of date of harvesting on the crop characters, yield components, yield and quality of tropical sugar beet.

\begin{tabular}{|c|c|c|c|c|c|c|c|c|c|c|c|}
\hline $\begin{array}{l}\text { Time of } \\
\text { harvesting }\end{array}$ & $\begin{array}{c}\text { Plant } \\
\text { height } \\
\text { (cm) }\end{array}$ & $\begin{array}{l}\text { No. of } \\
\text { leaves } \\
\text { plant }^{-1}\end{array}$ & $\begin{array}{l}\text { Chlorophyll } \\
\text { content } \\
\text { (SPAD } \\
\text { value) }\end{array}$ & $\begin{array}{l}\text { Shoot } \\
\text { length } \\
(\mathrm{cm})\end{array}$ & $\begin{array}{l}\text { Top } \\
\text { weight } \\
\text { plant }^{-1} \\
\text { (g) }\end{array}$ & $\begin{array}{l}\text { Top } \\
\text { yield } \\
\left(\mathrm{t} \mathrm{h} \mathrm{ha}^{-1}\right)\end{array}$ & $\begin{array}{l}\text { Beet } \\
\text { length } \\
\text { (cm) }\end{array}$ & $\begin{array}{l}\text { Beet } \\
\text { girth } \\
(\mathrm{cm})\end{array}$ & $\begin{array}{l}\text { Individual } \\
\text { beet } \\
\text { weight }(\mathrm{g})\end{array}$ & $\begin{array}{l}\text { Beet } \\
\text { yield } \\
\left(\mathrm{t} \mathrm{ha}^{-1}\right)\end{array}$ & $\begin{array}{l}\text { Brix } \\
\text { (\%) }\end{array}$ \\
\hline 135 DAS & $40.71 a$ & $13.53 a$ & $42.79 a$ & $34.47 a$ & $115.90 a$ & $11.59 a$ & $20.28 b$ & $22.07 \mathrm{~b}$ & $411.09 b$ & $41.11 b$ & $14.66 a$ \\
\hline 155 DAS & $37.21 b$ & $10.76 \mathrm{~b}$ & $33.74 b$ & $32.38 \mathrm{~b}$ & $84.07 b$ & $8.40 \mathrm{~b}$ & $24.26 a$ & $25.40 a$ & $536.07 a$ & $53.60 a$ & $14.28 b$ \\
\hline Sx & 0.345 & 0.144 & 0.324 & 0.335 & 1.91 & 0.117 & 0.164 & 0.237 & 7.04 & 1.31 & 0.112 \\
\hline $\begin{array}{l}\text { Level of } \\
\text { significant }\end{array}$ & $* *$ & $* *$ & $* *$ & $* *$ & $* *$ & $* *$ & $* *$ & $* *$ & $* *$ & $* *$ & $*$ \\
\hline CV (\%) & 4.06 & 5.46 & 3.89 & 4.60 & 8.80 & 5.37 & 3.38 & 4.58 & 6.81 & 6.81 & 3.57 \\
\hline
\end{tabular}

In a column, mean values with same letter (s) or without letter do not differ significantly whereas mean values with dissimilar letter differ significantly (as per DMRT); ${ }^{* *}=$ Significant at $1 \%$ level of probability, ${ }^{*}=$ Significant at $5 \%$ level of probability. 


\section{Beet length}

The beet length affected due to variety ranged from $20.83 \mathrm{~cm}$ to $23.50 \mathrm{~cm}$ (Table 1). The longest beet $(23.50 \mathrm{~cm}$ ) was obtained in SV 894 which was at par with SV $889(22.75 \mathrm{~cm})$ and SV 892 $(22.58 \mathrm{~cm})$ while the shortest beet $(20.83 \mathrm{~cm})$ was recorded in SV 893. Inherent characters of plants are responsible for variation in beet length. Beet length differs with variety that was reported elsewhere (Paul et al., 2018a; Paul et al., 2018b; Bairagi et al., 2013 and Islam et al., 2012). There was a significant effect of date of harvesting on beet length. The longest beet $(24.26 \mathrm{~cm})$ was observed when it was harvested at 155 DAS whereas the lowest beet $(20.28 \mathrm{~cm})$ was recorded from the date of harvesting at 135 DAS. Beet length increased gradually from first harvest to second harvest. This result was similar to Aly (2012) who stated that at second harvest beet got adequate time for root development. A significant variation of beet length was found due to interaction effect of varieties and date of harvesting. The longest beet (25.67 $\mathrm{cm}$ ) was obtained in SV 894 with influential date of harvesting at 155 DAS which was at par with SV $889(25.33 \mathrm{~cm})$ and SV 892 $(25.33 \mathrm{~cm})$ associated with harvesting date at 155 DAS and the shortest beet $(19.83 \mathrm{~cm})$ was observed in SV 892 with the harvesting date at 135 DAS (Table 3). Delay harvesting enhanced beet length that was reported by Aly (2012).

\section{Beet girth}

The beet girth showed a significant response to varieties. Beet girth observed due to varieties ranged from $21.67 \mathrm{~cm}$ to 26.50 $\mathrm{cm}$ (Table 1). The highest beet girth $(26.50 \mathrm{~cm})$ was obtained in SV 892 followed by KWS Danicia $(24.25 \mathrm{~cm})$ and the lowest one $(21.67 \mathrm{~cm})$ was found in SZ 35 . The similar results were also reported by Paul et al. (2018b) and Bairagi et al. (2013) who showed that beet girth differed significantly according to variety. A significant variation of beet girth was observed in response to date of harvesting (Table 2). Higher beet girth $(25.40 \mathrm{~cm})$ was obtained at 155 DAS harvest and lower beet girth $(22.07 \mathrm{~cm})$ was recorded at 135 DAS harvest. Beet girth was higher in response of early to delay harvesting that was reported by Islam et al. (2012). Beet girth had significant effect due to interaction effect of variety and date of harvesting. The maximum beet girth $(28.33 \mathrm{~cm})$ was obtained in SV 892 associated with the harvesting date at 155 DAS which was statistically identical with SV 894 in according to harvesting date at 155 DAS whereas the minimum beet girth $(20.50 \mathrm{~cm})$ was obtained in SV 889 with the harvesting date at 135 DAS (Table 3). Similar result was reported by Aly (2012) who showed that delay harvesting of some sugar beet varieties influenced the beet girth.

Table 3. Interaction effects of variety and date of harvesting on the crop characters, yield components and yield of tropical sugar beet.

\begin{tabular}{|c|c|c|c|c|c|c|c|c|c|c|c|}
\hline $\begin{array}{l}\text { Interaction } \\
\text { (Variety } \times \\
\text { time of } \\
\text { harvest) }\end{array}$ & $\begin{array}{l}\text { Plant } \\
\text { height } \\
(\mathrm{cm})\end{array}$ & $\begin{array}{l}\text { Number } \\
\text { of leaves } \\
\text { plant }^{-1}\end{array}$ & $\begin{array}{c}\text { Leaf } \\
\text { Chlorophyll } \\
\text { content } \\
\text { (SPAD } \\
\text { value at } \\
\text { harvest) }\end{array}$ & $\begin{array}{c}\text { Shoot } \\
\text { length } \\
(\mathrm{cm})\end{array}$ & $\begin{array}{l}\text { Top weight } \\
\text { plant }^{-1} \\
\text { (g) }\end{array}$ & $\begin{array}{c}\text { Top } \\
\text { yield } \\
\left(\mathrm{t} \mathrm{ha}^{-1}\right)\end{array}$ & $\begin{array}{l}\text { Beet } \\
\text { length } \\
(\mathrm{cm})\end{array}$ & $\begin{array}{c}\text { Beet } \\
\text { girth }(\mathrm{cm})\end{array}$ & $\begin{array}{l}\text { Individual } \\
\text { beet } \\
\text { weight } \\
\text { (g) }\end{array}$ & $\begin{array}{l}\text { Beet } \\
\text { yield } \\
\left(\mathrm{t} \mathrm{ha}^{-1}\right)\end{array}$ & Brix (\%) \\
\hline $\mathrm{V}_{1} \times \mathrm{H}_{1}$ & $41.44 b c$ & 14.28ab & $46.65 a b$ & 31.17ef & $152.00 a$ & $15.20 \mathrm{a}$ & $20.17 \mathrm{de}$ & $20.50 \mathrm{f}$ & $462.30 \mathrm{c}$ & $46.23 c$ & $14.67 \mathrm{bcde}$ \\
\hline $\mathrm{V}_{1} \times \mathrm{H}_{2}$ & $37.17 d$ & $10.00 \mathrm{ef}$ & $33.78 \mathrm{~d}$ & $35.37 \mathrm{bc}$ & $90.00 f g h$ & $9.00 f g h$ & $25.33 a$ & $25.50 \mathrm{bc}$ & $549.80 \mathrm{~b}$ & $54.98 b$ & 15.33ab \\
\hline $\mathrm{V}_{2} \times \mathrm{H}_{1}$ & $45.17 a$ & $13.05 \mathrm{bcd}$ & $45.32 b$ & $40.83 a$ & $125.00 \mathrm{~b}$ & $12.50 \mathrm{~b}$ & $19.83 e$ & $24.67 b c$ & $477.50 c$ & $47.75 c$ & $14.33 \mathrm{cdef}$ \\
\hline $\mathrm{V}_{2} \times \mathrm{H}_{2}$ & $37.50 \mathrm{~d}$ & $12.67 \mathrm{~cd}$ & $35.07 d$ & $35.17 \mathrm{bcd}$ & 80.83ghi & 8.08hi & $25.33 a$ & $28.33 a$ & $511.50 \mathrm{bc}$ & $51.15 b c$ & $14.00 \mathrm{efg}$ \\
\hline $\mathrm{V}_{3} \times \mathrm{H}_{1}$ & $41.33 b c$ & $13.28 \mathrm{bcd}$ & $48.13 a$ & 32.33de & $108.00 \mathrm{cde}$ & $10.80 \mathrm{~cd}$ & $19.83 e$ & 21.83def & 343.20de & $34.32 \mathrm{de}$ & 15.00abcd \\
\hline $\mathrm{V}_{3} \times \mathrm{H}_{2}$ & 42.67ab & $11.00 \mathrm{e}$ & $33.72 d$ & $32.67 \mathrm{cde}$ & 91.83efgh & $9.18 \mathrm{fg}$ & $21.83 c$ & $23.83 \mathrm{~cd}$ & $503.50 \mathrm{bc}$ & $50.35 \mathrm{bc}$ & $15.83 a$ \\
\hline $\mathrm{V}_{4} \times \mathrm{H}_{1}$ & $39.94 \mathrm{bcd}$ & 13.89abc & $44.41 \mathrm{~b}$ & 33.67cde & $103.30 \mathrm{cdf}$ & 10.33de & $21.33 \mathrm{~cd}$ & $21.17 f$ & $502.00 \mathrm{bc}$ & $50.20 \mathrm{bc}$ & 14.33cdef \\
\hline $\mathrm{V}_{4} \times \mathrm{H}_{2}$ & $38.00 \mathrm{~d}$ & $9.67 f$ & $35.20 \mathrm{~d}$ & $29.50 f$ & 95.17defg & 9.51ef & $25.67 a$ & 26.67ab & $681.20 a$ & $68.12 a$ & 14.33cdef \\
\hline $\mathrm{V}_{5} \times \mathrm{H}_{1}$ & $39.50 \mathrm{~cd}$ & $12.33 d$ & $38.86 c$ & 33.67cde & 95.33defg & $9.53 \mathrm{ef}$ & $19.67 \mathrm{e}$ & $20.83 f$ & $398.30 d$ & $39.83 d$ & 15.00abcd \\
\hline $\mathrm{V}_{5} \times \mathrm{H}_{2}$ & $37.33 d$ & 10.00ef & $34.24 d$ & $32.33 \mathrm{de}$ & $70.50 \mathrm{i}$ & $7.05 j$ & $23.17 b$ & 22.50def & $460.00 c$ & $46.00 c$ & $13.67 \mathrm{fg}$ \\
\hline $\mathrm{V}_{6} \times \mathrm{H}_{1}$ & $39.44 c d$ & $13.22 \mathrm{bcd}$ & $35.83 d$ & $37.17 \mathrm{~b}$ & $110.70 \mathrm{bcd}$ & $11.07 \mathrm{~cd}$ & $19.83 \mathrm{e}$ & 21.83 ef & $374.00 \mathrm{de}$ & $37.40 \mathrm{de}$ & $15.17 \mathrm{abc}$ \\
\hline $\mathrm{V}_{6} \times \mathrm{H}_{2}$ & $34.33 e$ & $11.00 \mathrm{e}$ & $28.77 \mathrm{e}$ & $32.50 \mathrm{cde}$ & 83.67ghi & 8.36ghi & $25.00 \mathrm{a}$ & $26.17 b$ & $561.80 \mathrm{~b}$ & $56.18 b$ & $13.17 \mathrm{~g}$ \\
\hline $\mathrm{V}_{7} \times \mathrm{H}_{1}$ & $38.17 d$ & $14.67 a$ & $40.38 c$ & $32.50 \mathrm{cde}$ & $117.00 \mathrm{bc}$ & $11.70 b c$ & $21.33 c d$ & 23.67cde & $320.30 \mathrm{e}$ & $32.03 \mathrm{e}$ & $14.17 \mathrm{def}$ \\
\hline $\mathrm{V}_{7} \times \mathrm{H}_{2}$ & $33.50 \mathrm{e}$ & $11.00 \mathrm{e}$ & $35.41 d$ & $29.17 f$ & 76.50hi & $7.650 \mathrm{ij}$ & $23.50 \mathrm{~b}$ & $24.83 b c$ & $484.70 c$ & $48.47 c$ & $13.67 \mathrm{fg}$ \\
\hline Sx & 0.914 & 0.383 & 0.860 & 0.889 & 5.08 & 0.310 & 0.434 & 0.627 & 18.63 & 1.86 & 0.298 \\
\hline $\begin{array}{l}\text { Level of } \\
\text { significant }\end{array}$ & $* *$ & $* *$ & $* *$ & $* *$ & $* *$ & $* *$ & $* *$ & $* *$ & $* *$ & $* *$ & $* *$ \\
\hline CV (\%) & 4.06 & 5.46 & 3.89 & 4.60 & 8.80 & 5.37 & 3.38 & 4.58 & 6.81 & 6.81 & 3.57 \\
\hline
\end{tabular}

In a column, mean values with same letter (s) or without letter do not differ significantly whereas mean values with dissimilar letter differ significantly (as per DMRT); ${ }^{* *}$ $=$ Significant at $1 \%$ level of probability $; \mathrm{V}_{1}=\mathrm{SV} 889, \mathrm{~V}_{2}=\mathrm{SV} 892, \mathrm{~V}_{3}=\mathrm{SV} 893, \mathrm{~V}_{4}=\mathrm{SV} 894, \mathrm{~V}_{5}=\mathrm{SZ} 35, \mathrm{~V}_{6}=\mathrm{KWS} \mathrm{Serenada}$ and $\mathrm{V}_{7}=\mathrm{KWS}$ Danicia, $\mathrm{H}_{1}=135 \mathrm{DAS}, \mathrm{H}_{2}=$ 155 DAS. 
Individual beet weight

Different variety exhibited significant influence on beet fresh weight plant ${ }^{-1}$. The individual beet weight ranged from $402.5 \mathrm{~g}$ to $591.6 \mathrm{~g}$ (Table 1). The highest beet weight $(591.6 \mathrm{~g})$ was recorded in SV 894 followed by SV 889 , SV 892 and KWS Serenda while the lowest one (402.5 g) was found in KWS Danicia. This variation might be occurred due to genetic potentiality in variety. The findings are in agreement with that of Islam et al. (2012) and Paul et al. (2018b) who reported that individual beet weight differed significantly due to varietal genetic differences. A gradual increase in beet fresh weight was observed due to date of harvesting. The highest individual beet weight (536.07 g) was recorded when the crop was harvested at 155 DAS whereas the lowest individual beet weight (411.09 g) was observed at 135 DAS. Islam et al. (2012) showed that beet weight increased at later harvest due to stunted vegetative growth and nutrient substances stored in beet. Individual beet weight also showed a significant response due to interaction effect between variety and date of harvesting. The maximum beet weight (681.2 g) was recorded in SV 894 with the influential date of harvesting at 155 DAS followed by KWS Serenda $(561.8 \mathrm{~g})$ with the harvesting date at 155 DAS and the minimum beet weight ( $320.3 \mathrm{~g}$ ) that was observed in KWS Danicia according to harvesting date at 135 DAS (Table 3). Al-Gateem (2000) showed that individual beet weight increased due to delay harvest because of enough time to increase individual beet weight at second harvest.

\section{Beet yield}

Beet yield varied due to variety that ranged from 40.25 to 59.16 $\mathrm{t} \mathrm{ha}^{-1}$ (Table 1). The highest beet yield $\left(59.16 \mathrm{t} \mathrm{ha}^{-1}\right)$ was recorded in SV 894 followed by SV 889 (50.61 $\mathrm{t} \mathrm{ha}^{-1}$ ), which was at par with SV 892 (49.45 $\mathrm{t} \mathrm{ha}^{-1}$ ) and KWS Serenada (46.79 $\mathrm{t} \mathrm{ha}^{-1}$ ) while the lowest one (40.25 t ha ${ }^{-1}$ ) was found in KWS Danicia (Figure 1). The production potential of varieties differed due to variation of genetic characteristics. Beet yield varied due to varietal differences was reported by Islam et al. (2012) and Rahman et al. (2006). Date of harvesting significantly influences beet yield (Table 2). The maximum beet yield $\left(53.60 \mathrm{t} \mathrm{ha}^{-1}\right)$ was

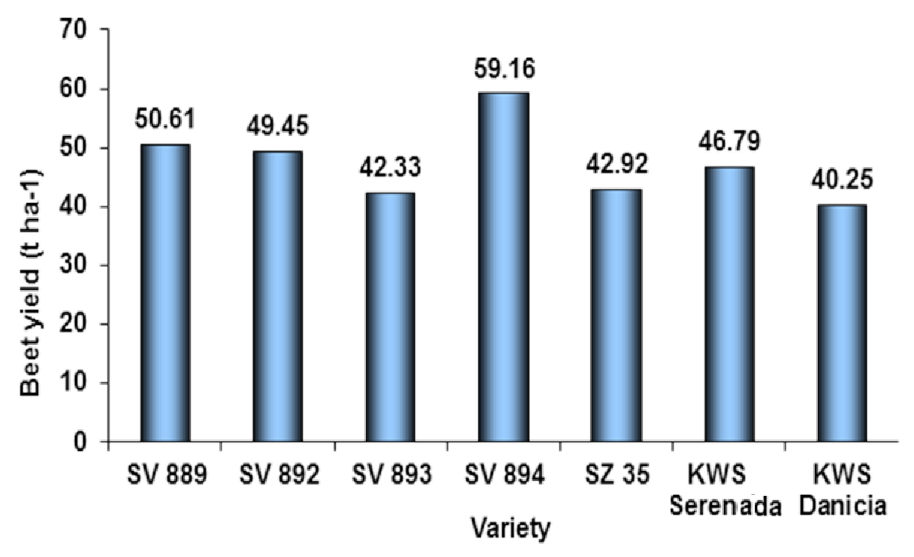

Figure 1. Effect of variety on beet yield of tropical sugar beet (LSD $p \leq$ 0.05). recorded when the crop was harvested at 155 DAS and minimum beet yield (41.11 $\mathrm{t} \mathrm{ha}^{-1}$ ) was observed at 135 DAS. Beet yield became higher from early to delay harvest due to extending the growth period and subsequently enrichment of root than earlier harvest. Similar results were reported by Hemayati et al. (2012) and Heidari et al. (2008). Beet yield was also significantly affected due to interaction between variety and date of harvesting (Table 3). The highest beet yield $(68.12 \mathrm{t}$ $\mathrm{ha}^{-1}$ ) was recorded in SV 894 at 155 DAS harvest followed by KWS Serenda (56.18 $\mathrm{t} \mathrm{ha}^{-1}$ ) along with 155 DAS harvest while the lowest beet yield (32.03 $\mathrm{t} \mathrm{ha}^{-1}$ ) was obtained in KWS Danicia with 135 DAS harvest. Later harvest increased beet yield and white sugar content (Lauer, 1997).

\section{Brix (\%) in juice}

Different variety exhibited significant influence in brix (\%) in juice. Brix (\%) in juice was affected due to varieties ranging from $13.92 \%$ to $15.42 \%$ (Table 1 ). The maximum brix (15.42\%) was recorded in SV 893 which was at par with SV 889 (15.00\%) and the minimum brix (13.92\%) found in KWS Danicia (Figure 2). Brix (\%) in juice differed due to variety was reported elsewhere (Hossain et al., 2011; Paul et al., 2018a and Paul et al., 2018b). Brix was significantly influenced by date of harvesting. The maximum brix (14.66 \%) observed at 135 DAS harvest while the minimum brix (14.28\%) was recorded at 155 DAS harvest. This might be happened due to increase in temperature and respiration in delay harvest. Similar trend was reported elsewhere (Hemayati et al., 2012; Pavlů et al., 2017 and Paul et al., 2018a). Interaction effect of variety and date of harvesting had significant effect on brix (\%). The maximum brix (15.83\%) was observed in SV 893 with 155 DAS harvest which was at par with SV 889 (15.33\%) with 155 DAS harvest and the minimum brix (13.17\%) was recorded in KWS Serenda harvested at 155 DAS (Table 3). Similar results were reported by Jozefyova et al. (2003), that a delay in sugar beet harvest decrease sucrose percentage. In Bangladesh, heavy rain in March-April increases soil moisture, with relatively high temperature in environment might be responsible for reduction of brix (\%) in juice at delay harvest.

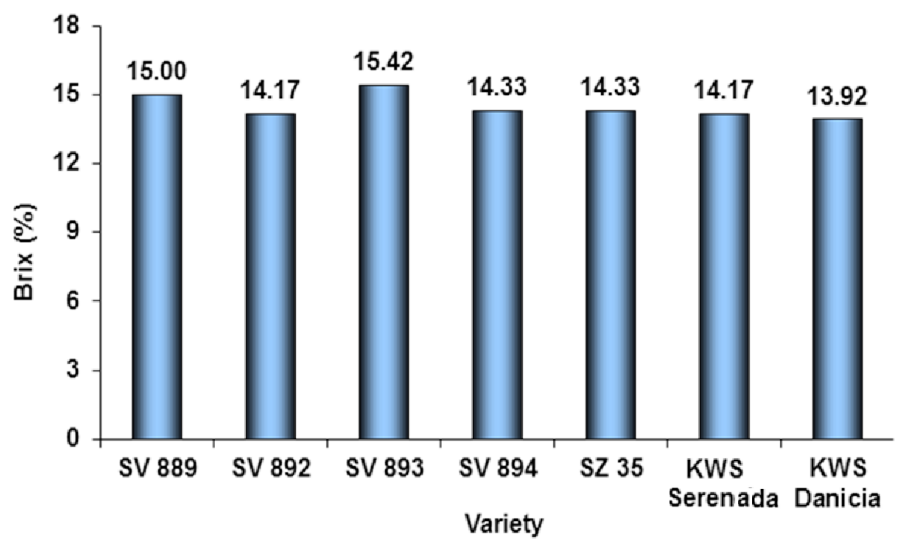

Figure 2. Effect of variety on brix (\%) in juice of tropical sugar beet (LSD $p \leq 0.05$ ). 
Functional relationship between leaf chlorophyll content (SPAD value) at harvest and yield of tropical sugar beet (TSB) Leaf chlorophyll content (SPAD value) is one of the most important determinants of yield of sugar beet. SPAD value of tropical sugar beet increased progressively over time attaining the highest at 80 DAS and then decreased irrespective of treatments because of drying and decaying of leaves (Paul et al., 2018a and Paul et al., 2018b). Regression analysis was done to quantify the relationship between SPAD values at harvest and yield of tropical sugar beet. The relationship of SPAD value at harvest and beet yield of TSB was determined by using interaction data between variety and date of harvest. A negative linear relationship between SPAD value at harvest and yield of TSB was observed, indicating that lower the SPAD value at harvest higher the sugar beet yield. The regression equation (Figure 3) indicates that decrease in SPAD value at harvest would lead to an increase in the beet yield. The functional relationship was significant at $p \leq 0.01$. The functional relationship can be determined by the regression equation $Y=-0.7611 x+76.486\left(R^{2}=\right.$ $0.219)$. It was revealed that $21 \%$ of the variation in yield could be explained from the variation in SPAD value at harvest.

\section{Functional relationship between beet length and yield of TSB}

Beet length is the most important yield components of TSB. Regression analysis was done to measure the relationship between beet length and yield of tropical sugar beet. A positive linear relationship between beet length and yield of tropical sugar beet was observed, which indicated that higher the beet length higher the beet yields. The regression equation indicates that an increase in beet length would lead to an increase in the beet yield of tropical sugar beet (Figure 4). The functional relationship was significant at $\mathrm{p} \leq 0.01$. The functional relationship can be determined by the regression equation $Y=3.0577 x$ $20.746\left(R^{2}=0.5709\right)$. The functional relationship showed that $57 \%$ of the variation in yield could be explained from the variation in beet length.

Functional relationship between individual beet weight and yield of TSB

A positive linear relationship between yield and individual beet weight of TSB was observed, which indicated that higher the individual beet weight the higher the beet yield. The relationship of individual beet weight and beet yield of TSB was determined by using interaction data between variety and fertilizer application. The response of individual beet weight to the yield of TSB followed a linear positive relationship which could be adequately described by regression equation. The regression equation indicates that an increase in individual beet weight would lead to an increase in the beet yield of TSB (Figure 5). The functional relationship was significant at $p \leq 0.01$. The functional relationship can be determined by the regression equation $Y=99.86 x+0.2096\left(R^{2}=\right.$ 0.9995). The functional relationship revealed that $99 \%$ of the variation in yield could be explained from the variation in individual beet weight. Similar result was reported by Paul et al. (2018a).

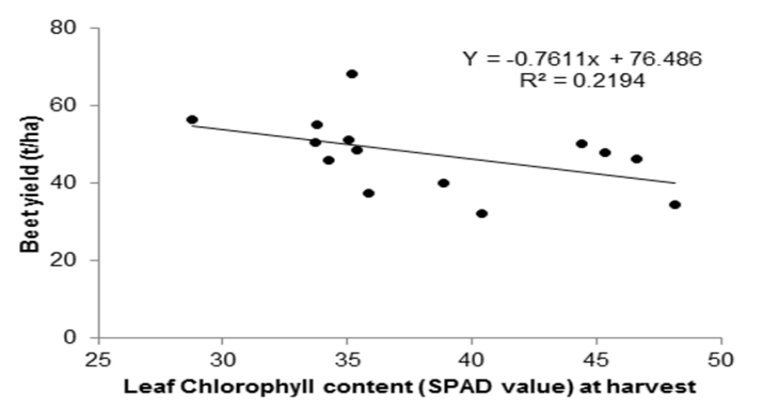

Figure 3. Functional relationship between leaf chlorophyll content (SPAD value) at harvest and yield of tropical sugar beet.

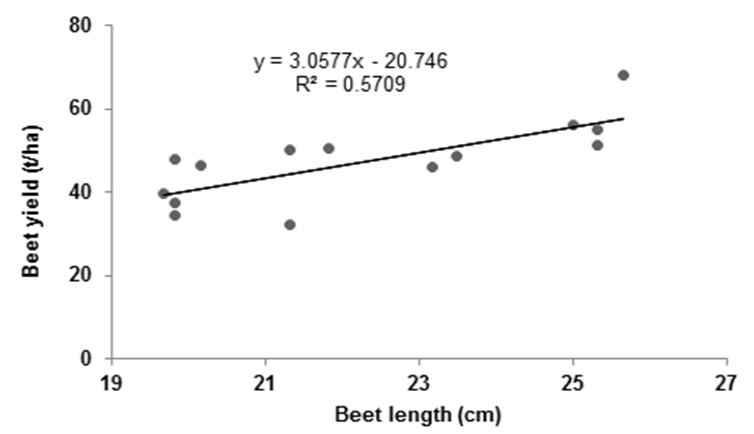

Figure 4. Functional relationship between beet length and yield of tropical sugar beet.

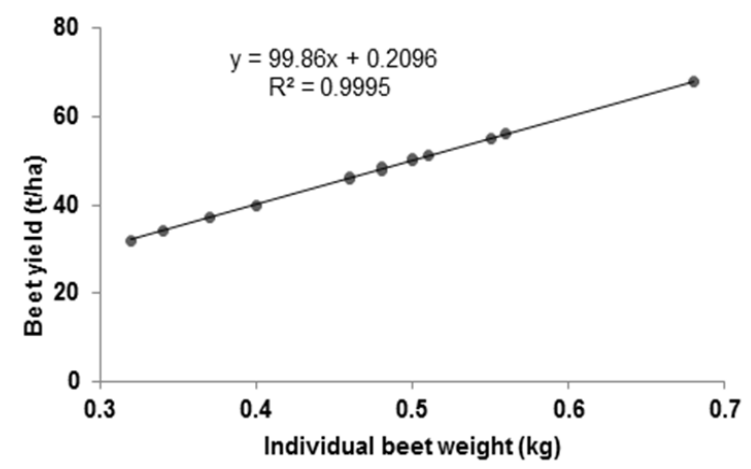

Figure 5. Functional relationship between individual beet weight and yield of tropical sugar beet.

Conclusion

The highest beet length, individual beet weight and beet yield were recorded in SV 894 while the maximum number of leaves plant $^{-1}$, shoot length and beet girth were recorded in SV 892, and the highest plant height, leaf chlorophyll content (SPAD value) at harvest and brix were observed in SV 893. The lowest plant height, shoot length, individual beet weight, beet yield and brix were observed in KWS Danicia while the lowest number of leaves plant $^{-1}$ and beet girth were recorded in SZ 35 and the lowest beet length was observed in SV 893. In case of date of harvesting, the highest plant height, number of leaves plant ${ }^{-1}$, leaf chlorophyll content (SPAD value) at harvest, shoot length, top weight plant ${ }^{-1}$, top yield and brix were recorded at 135 DAS and the highest beet length, beet girth, individual beet weight and beet yield were observed at 155 DAS harvest while their lowest values were recorded at 135 DAS harvest. In interaction, the highest beet length, individual beet weight and beet yield were recorded in SV 894 with 155 DAS harvest whereas the lowest yield was recorded in the interaction in KWS Danicia with 135 DAS harvest. Therefore, it may be concluded that SV 894 appears as the promising variety that can be harvested at 155 DAS. 


\section{ACKNOWLEDGEMENTS}

The financial assistance of Bangladesh Agricultural University Research System (BAURES) (2015/08/BAU) to conduct the research project is thankfully acknowledged.

Open Access: This is an open access article distributed under the terms of the Creative Commons Attribution 4.0 License, which permits unrestricted use, distribution, and reproduction in any medium, provided the original author(s) if the sources are credited.

\section{REFERENCES}

Abo-El Magd, B.M., Ebraheim, M.F. and Aboushady, K.H.A. (2003). Some chemical and technological characteristics by planting methods and different harvesting dates. Journal of Agricultural Sciences, Mansoura University, 28(7): 5115-5128.

Aly, M.S.M. (2012). Performance study of some sugar beet varieties under sowing and harvesting dates. Journal of Plant Production. Mansoura University, 3(9): 2439-2449.

Al-Gateem, M.M. (2000). Effect of sowing date and densities on growth and production of sugarbeet (Beta vulgaris L.). Journal of Agronomy, 6(3): 144-157.

Azzazy, N.B., Shalaby. N.M.S. and Abd El-Razek, A.M. (2007). Effect of planting density and days to harvest on yield and quality of some sugar beet varieties under Fayoum condition. Egyptian Journal of Applied Science, 22(12): 101-114.

Bairagi, A, Paul, S.K. and Kader, M.A. (2013). Yield of tropical sugarbeet as influenced by variety and rate of fertilizer application. Pakistan Sugar Journal, 28(4): 13-20.

El-Sheikh, S.R.E., Khaled, K.A.M. and Enan, S.A.A.M. (2009). Evaluation of some sugar beet varieties under three harvesting dates. Journal of Agricultural Science, Mansoura University, 34(3): 1559-1567.

Gomez, K.A. and Gomez, A.A. (1984). Statistical procedure for agricultural research. John Wiley and Sons, New York, econd edition. pp. 680.

Heidari, G., Sohrabi, Y. and Esmailpoor, B. (2008). Influence of harvesting time on yield and yield components of sugar beet. Journal of Agriculture, Forestry and the Social Sciences, 4 (2): 69-73.

Hemayati, S.S., Shirzadi, M.H., Aghaeezadeh, M., Taleghani, D.F., Javaheri, M.A. and Aliasghari, A. (2012). Evaluation of sowing and harvesting date effects on yield and quality of five sugar beet cultivars in Jiroft region (autumn planting). Journal of Sugar Beet, 28(1): 13-21.

Hossain, M.M., Kader, M.A. and Kashem M.A. (2011). Effect of sowing date and variety on the yield of tropical sugar beet (Beta vulgaris L.). Bangladesh Agronomy Journal, 14(1 \& 2): 95 $-101$.

Islam, M.S., Ahmed, S., Uddin, M.N. and Sattar, M.A. (2012). Evaluation of tropical sugarbeet (Beta vulgaris $L$ ) genotypes under Bangladesh condition. Bangladesh Journal of Agricultural Research, 37(4): 721-728.
Jozefyova, L., Pulkrabek, J. and Urban, J. (2003). Effect of harvest time on sugar beet fertilized with increased nitrogen. Journal of Food Agriculture and Environment, 2: 232-237.

Lauer, J.G. (1995). Plant density and nitrogen rate effects on sugar beet yield and quality early in harvest. Agronomy Journal, 87: 586-591.

Lauer, J.G. (1997). Sugar beet performance and interactions with planting date, genotype, and harvest date. Agronomy Journal, 89(3): 469-475, http://corn.agronomy.wisc.edu/pubs/JL_JournalArticles/ 089-03-0469.pdf

Oldemeyer, P.K., Erichsen, A.W. and Suzuki, A. (1997). Effect of harvest date on performance of sugar beet hybrids. Journal of the ASSBT, 19(4): 294-306.

Paul, S.K., Paul, U., Sarkar, M.A.R and Hossain, M.S. (2018a). Yield and quality of tropical sugarbeet as influenced by variety, spacing and fertilizer application. Sugar Tech, 20(2): 175-181, https://doi.org/10.1007/s12355-017-0545-3

Paul, S.K., Paul, S.C., Sarkar, M.A.R. and Hossain, M.S. (2018b). Influence of integrated nutrient management on the growth yield and sugar content of tropical sugar beet (Beta vulgaris L.). Pakistan Sugar Journal, 33(2): 11-22.

Pavlů, K., Chochola, J., Pulkrábek,J. and Urban, J. (2017). Influence of sowing and harvest dates on production of two different cultivars of sugar beet. Plant, Soil and Environment, 63(2):76-81, https://doi.org/10.17221/614/2016-PSE

Rahman, M.K., Kabir, R.L., Alam, M. J., Hossain, M. S. and Islam, A. K.M.R. (2006). Sugarbeet cultivation in Bangladesh. Bangladesh Sugarcane Research Institute, Ishurdi, Pabna, Bangladesh. pp. 1-7.

Rahman, M.S., Khatun, S. and Rahman, M.K. (2016). Sugarcane and sugar industry in Bangladesh: An overview. Sugar Tech, 18(6): 627-635, https://doi.org/10.1007/s12355-016-0489-z

Seadh, S.E., Attia, A.N., Said, E.M., El-Maghraby, S. and Ibrahim, M.E.M. (2013). Productivity and quality of sugarbeet as affecting by sowing method, weed control and $\mathrm{N}$ fertilizer level. Pakistan Journal of Biological Sciences, 16: 711-719.

Shalaby, N.M.E., Osman, A.M.H. and El Labbody, A.H.S.A. (2011). Evaluation of some sugarbeet varieties as affected by harvesting dates under newly reclaimed soil. Egyptian Journal of Agricultural Research, 89(2): 605-614, http://www.arc.sci.eg/ejar/UploadFiles/Publications/ 1137106.pdf

Shewate, S.R., Ghodke, P.V., Patil, S.S. and Shinde, S.H. (2009). Comparative performance of new tropicalized sugar beet (Beta vulgaris) varieties. Indian Sugar, 59(3): 27-32.

UNDP and FAO (1988). Land resources appraisal of Bangladesh for agricultural development, report-2. BARC, Dhaka, pp. 212-221.

Zhu, J., Tremblay, N. and Liang, Y. (2012). Comparing SPAD and at LEAF values for chlorophyll assessment in crop species. Canadian Journal of Soil Science, 92(4): 645-64, https://doi.org/10.4141/cjss2011-100 